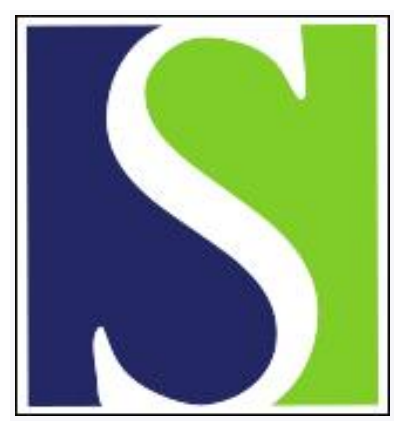

Scand J Work Environ Health 1998;24(3):206-212

https://doi.org/10.5271/sjweh.300

Issue date: Jun 1998

Work pace control and pregnancy health in a population-based sample of employed women in Norway

by Wergeland $\mathrm{E}$, Strand $\mathrm{K}$

The following article refers to this text: 2007;33(4):304-317

Key terms: back pain; birthweight; job control; pelvic pain; preeclampsia; prenatal care; stress; work break; work rate

This article in PubMed: www.ncbi.nlm.nih.gov/pubmed/9710373

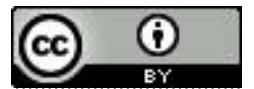




\title{
Work pace control and pregnancy health in a population-based sample of employed women in Norway
}

\author{
by Ebba Wergeland MD, ${ }^{1}$ Kitty Strand, $M D^{1}$
}

\begin{abstract}
Wergeland E, Strand K. Work pace control and pregnancy health in a population-based sample of employed women in Norway. Scand J Work Environ Health 1998;24(3):206-212.

Objectives This study explored the possible effects of power to control one's own work pace on pregnancy health. Methods Questionnaires were sent to all parturients in Norway between 16 October and 26 November 1989 for completion prior to discharge from the hospital; $87.2 \%$ responded. The study population comprised 3321 respondents with singleton pregnancies and paid work beyond the 3rd month of pregnancy. Power to control work pace was measured as self-reported influence on breaks and work pace and absence of external pacing. Pregnancy health was defined by the prevalence of preeclampsia, disabling posterior pelvic pain, low-back pain, and birthweight of $<2500 \mathrm{~g}$ for the offspring.

Results Pregnancy health improved with increasing power to control work pace, both in manual and nonmanual work. The risk decreased with increasing control for all 4 outcomes, but the impact on birthweight was restricted to nullipara. After adjustment for age, parity, education, smoking, and manual work, the decreasing trend remained significant for preeclampsia and low birthweight of the first born. In a comparison with women with the highest level of control, the adjusted odds ratios for women with no control were 1.6 [95\% confidence interval ( $95 \% \mathrm{CI})$ $0.9-3.1$ ] for preeclampsia, $1.6(95 \% \mathrm{Cr} 1.0-2.4)$ for disabling posterior pelvic pain, $1.3(95 \% \mathrm{Cl} 1.0-1.8)$ for low-back pain, and 2.5 (95\% Cl 0.9-6.8) for low birthweight (nullipara).

Conclusions Women with power to control their own work pace had better pregnancy health than women without such power. The results suggest increased individual control over work pace as a prime target for job adjustment during pregnancy.
\end{abstract}

Key terms back pain, birthweight, breaks, job control, pelvic pain, preeclampsia, prenatal care, stress, work rate.

Time aspects of work organization, like work pace and the duration and timing of rest periods, have received little attention in efforts to improve work conditions (1). According to recent surveys in Norway, workers' influence on their own work pace is decreasing, and women have less influence than men (2).

Optional choice of work pace in physically demanding work results in the adaptation of pace or intensity until the worker is utilizing $40-45 \%$ of his or her capacity (3). Sufficient breaks are important for endurance in physically demanding work (4-6). When the work rate is externally paced, the adaptation, which otherwise seems to protect against exertion, can be disturbed. Bodily stress reactions can be elicited even in the absence of physical strain (7). Plasma adrenaline tends to increase during externally paced mental work when compared with self-paced mental work (8).

For pregnant workers, lack of control over work pace may represent a particular disadvantage. Cardiovascular and musculoskeletal changes during pregnancy increase the risk of physical exertion (9) and orthopedic injuries (10). Moreover, strenuous work with lack of control over work pace may increase adverse effects when nutrition and oxygen supply to the fetus is already impaired (11).

Poor placental perfusion has been suggested as an initiating factor of the preeclamptic syndrome (12), and elevated levels of plasma adrenaline might aggravate this condition, which is characterized by increased pressor sensitivity (12). A couple of studies have pointed to physically strenuous work as a risk factor $(13-15)$.

Back pain in pregnancy may be related to serum relaxin levels (16), increased body mass, and reduced loadbearing capacity of the musculoskeletal system (17). Strenuous work, but also constrained or sitting postures, has been found to increase the risk of back pain $(18,19)$.

Posterior pelvic pain is a particular type of back pain that occurs in pregnancy (19), in Norway popularly known as "pelvic girdle loosening". The etiology is

Department of Preventive Medicine, Oslo University, Oslo, Norway.

Reprint requests to: Dr Ebba Wergeland, Department of Preventive Medicine, POB 1130 Blindern, 0317 Oslo, Norway. [e-mail: ebba.wergeland@samfunnsmed.uio.no] 
poorly understood, but physical fitness and optimal work techniques may have a less preventive effect than for other types of low-back pain (20).

The aim of the present study was to explore eventual effects of power to control one's own work pace on pregnancy health. Pregnancy health was defined by the prevalence of preeclampsia, disabling posterior pelvic pain, low-back pain, and low birthweight $(<2500 \mathrm{~g})$ of offspring.

\section{Subjects and methods}

Of the 6235 women who gave birth in Norway during a 6 weeks' period in 1989 ( 16 October - 26 November), $5438(87.2 \%)$ completed an extensive questionnaire after delivery, while still in the hospital. Altogether 4205 (77.3\%) of them had done paid work during their pregnancy. The response rates were low for non-Nordic citizens (47\%) and for women below 20 years of age $(70 \%)$, constituting together less than $10 \%$ of all the parturients.

The study population consisted of the 3321 respondents who had a singleton pregnancy and who continued to do paid work beyond the 3rd month of pregnancy.

The questionnaire covered information on demographic data, obstetric history, various aspects of pregnancy health and pregnancy outcome, and detailed information on work conditions in early pregnancy, at the time when the woman became aware of her pregnancy.

Preeclampsia was registered if the woman reported that both proteinuria and hypertension were diagnosed on more than 1 occasion during her pregnancy or that she was hospitalized due to hypertension (21).

Disabling posterior pelvic pain was defined by the first response alternative to the following 2 questions: "Did you suffer from pelvic girdle loosening in this pregnancy?" (yes; no); "Did pelvic girdle loosening make it difficult for you to manage housework?" (yes, to a large extent; yes, to some extent; no). The time of first occurrence was recorded by month of pregnancy.

Birthweight in grams was based on information given by the mothers. Low birthweight was defined as a birthweight of less than $2500 \mathrm{~g}$.

Low-back pain was defined by the first response alternative to the question: "Did you during this pregnancy suffer from ... pain in the lumbar region (lower part of back)?" (yes, frequently; yes, a few times; no, never).

Paid work included unpaid but income-generating work in family business, farming or fisheries and selfemployed work any time during pregnancy.

Occupation was recorded by questions used in the Labor Market Survey conducted by Statistics Norway, and it was coded by trained personnel according to the Standard Classification in Norwegian Official Statistics
(1965), based on the International Standard Classification of Occupations (ISCO, 1958).

A score for control over work pace, with values from 0 to 3 for increasing power to control, was based on the answers given to the following questions on influence on breaks, influence on work pace, and sources of external pacing (assigned values in parentheses): influence on breaks: "Could you usually leave the job for a short period, like 5-10 minutes, without need for a relief?" [yes, without problems (1); yes, but with problems (0); no (0)]; influence on work pace: "In some jobs you can decide yourself when to do the different tasks and at what pace. One may for instance choose to work somewhat faster some days and slower on other days. Did you have this opportunity?" [yes, daily more than half the work time (1); yes, daily, less than half the work time (1); sometimes, but not daily $(0)$; rarely or never $(0)$ ]; externally paced work: "Was your work pace any part of the time completely tied by assembly line or machines/the work pace of your fellow workers/supervision systems or wage systems (like bonus agreements, piecework or productivity control)?"' Work was considered externally paced (yes $=0$; no $=1$ ) if any of the 3 sources of external pacing occurred daily.

Intercorrelation between the 3 score items was low, with a Spearman correlation coefficient (22) of $\leq 0.3$ and Cronbach's alpha (23) of 0.4 .

Manual work was registered by the question "Did you have manual work, that is, did you exert yourself more than when standing, walking and moving normally?", with response alternatives and the exposure definition as for influence on work pace.

Lifting heavy loads of $10-20 \mathrm{~kg}$ was registered by the question "Did you frequently lift loads weighing between 10 and 20 kilos?" (yes, more than 20 times daily; yes, 10 to 20 times daily; yes, more than 20 times weekly; yes, less than 20 times weekly; rarely or never). The first 3 response alternatives defined exposure.

Influence on work content was registered with the question "Did you sometimes take part in decisions about how your work was to be carried out - for instance what should be done, how it should be done and with whom you should work?" (always; usually; usually not; never). The first 2 response alternatives defined exposure.

Work with video display terminals was recorded by the following question: "Did you work at a video display terminal?", with the response alternatives and exposure definition as for influence on work pace.

Weekly hours of work were registered for housework $(<10,10-19,20-29, \geq 30$ hours $)$ and paid work ( $<20$, $20-34,35-40,>40$ hours) separately. Hours in paid work included overtime and secondary employment. The 2 variables were each dichotomized in 2 ways: $<20 / \geq 20$ or $<30 / \geq 30$ for hours of housework and $<35 / \geq 35$ or $\leq 40 /$ $>40$ for hours of paid work. 
Table 1. Prevalence ${ }^{a}$ of preeclampsia (PE), disabling posterior pelvic pain (DPP), low-back pain (LBP) and low birthweight (LBW), according to work conditions and the maternal characteristics of the women in paid work beyond the 3rd month of pregnancy, with single births.

\begin{tabular}{|c|c|c|c|c|c|}
\hline Category & $\begin{array}{l}\text { Number of } \\
\text { respondents }\end{array}$ & $\begin{array}{l}P E \\
\%\end{array}$ & $\underset{\%}{\mathrm{DPP}}$ & $\begin{array}{c}\mathrm{LBP} \\
\%\end{array}$ & $\underset{\%}{\text { LBW }}$ \\
\hline \multicolumn{6}{|l|}{ Influence on breaks } \\
\hline $\begin{array}{l}\text { Yes } \\
\text { No }\end{array}$ & $\begin{array}{l}2090 \\
1182\end{array}$ & $\begin{array}{l}5.0 \\
5.9\end{array}$ & $\begin{array}{c}8.5 \\
11.8^{* *}\end{array}$ & $\begin{array}{l}36.0 \\
41.7^{\star *}\end{array}$ & $\begin{array}{l}2.9 \\
3.9\end{array}$ \\
\hline \multicolumn{6}{|l|}{ Influence on work pace } \\
\hline $\begin{array}{l}\text { Yes } \\
\text { No }\end{array}$ & $\begin{array}{l}1154 \\
2118\end{array}$ & $\begin{array}{l}4.2 \\
6.1^{*}\end{array}$ & $\begin{array}{l}9.2 \\
9.8\end{array}$ & $\begin{array}{l}34.5 \\
40.1^{\text {** }}\end{array}$ & $\begin{array}{l}2.3 \\
3.8^{*}\end{array}$ \\
\hline \multicolumn{6}{|l|}{ Externally paced work } \\
\hline $\begin{array}{l}\text { Yes } \\
\text { No }\end{array}$ & $\begin{array}{r}793 \\
2487\end{array}$ & $\begin{array}{l}6.1 \\
5.2\end{array}$ & $\begin{array}{r}10.4 \\
9.4\end{array}$ & $\begin{array}{l}43.7 \\
36.4^{\star * *}\end{array}$ & $\begin{array}{r}3.2 \\
+3.3\end{array}$ \\
\hline \multicolumn{6}{|l|}{ Manual work } \\
\hline $\begin{array}{l}\text { Yes } \\
\text { No }\end{array}$ & $\begin{array}{l}1216 \\
2057\end{array}$ & $\begin{array}{l}6.0 \\
5.0\end{array}$ & $\begin{array}{r}10.4 \\
9.2\end{array}$ & $\begin{array}{l}47.0 \\
32.9^{* * *}\end{array}$ & $\begin{array}{r}3.8 \\
\times \quad 3.0\end{array}$ \\
\hline \multicolumn{6}{|l|}{$\begin{array}{l}\text { Lifting heavy loads, } \\
10-20 \mathrm{~kg}\end{array}$} \\
\hline $\begin{array}{l}\text { Yes } \\
\text { No }\end{array}$ & $\begin{array}{r}782 \\
2502\end{array}$ & $\begin{array}{l}7.7 \\
4.7^{\star \star}\end{array}$ & $\begin{array}{c}11.7 \\
9.1 *\end{array}$ & $\begin{array}{l}48.7 \\
34.8^{* \star *}\end{array}$ & $\begin{array}{l}4.5 \\
* \\
* 2.9^{*}\end{array}$ \\
\hline \multicolumn{6}{|l|}{ Influence on work content } \\
\hline $\begin{array}{l}\text { Yes } \\
\text { No }\end{array}$ & $\begin{array}{r}2346 \\
916\end{array}$ & $\begin{array}{l}5.3 \\
5.4\end{array}$ & $\begin{array}{l}9.6 \\
9.8\end{array}$ & $\begin{array}{l}35.6 \\
44.4^{* * *}\end{array}$ & $\begin{array}{r}3.0 \\
\times \\
3.6\end{array}$ \\
\hline \multicolumn{6}{|l|}{$\begin{array}{l}\text { Work with video display } \\
\text { terminals }\end{array}$} \\
\hline $\begin{array}{l}\text { Yes } \\
\text { No }\end{array}$ & $\begin{array}{r}758 \\
2429\end{array}$ & $\begin{array}{l}4.8 \\
5.7\end{array}$ & $\begin{array}{l}8.0 \\
9.9\end{array}$ & $\begin{array}{l}34.1 \\
38.8^{*}\end{array}$ & $\begin{array}{l}2.8 \\
3.5\end{array}$ \\
\hline \multicolumn{6}{|l|}{$\begin{array}{l}\text { Weekly hours of paid } \\
\text { work } \geq 35\end{array}$} \\
\hline $\begin{array}{l}\text { Yes } \\
\text { No }\end{array}$ & $\begin{array}{l}2020 \\
1148\end{array}$ & $\begin{array}{l}5.6 \\
5.5\end{array}$ & $\begin{array}{l}9.0 \\
11.3^{*}\end{array}$ & $\begin{array}{l}37.2 \\
40.3\end{array}$ & $\begin{array}{l}3.6 \\
3.1\end{array}$ \\
\hline \multicolumn{6}{|l|}{$\begin{array}{l}\text { Weekly hours of paid } \\
\text { work }>40\end{array}$} \\
\hline $\begin{array}{l}\text { Yes } \\
\text { No }\end{array}$ & $\begin{array}{r}352 \\
2816\end{array}$ & $\begin{array}{l}5.1 \\
5.6\end{array}$ & $\begin{array}{r}7.2 \\
10.1\end{array}$ & $\begin{array}{l}32.3 \\
39.0^{*}\end{array}$ & $\begin{array}{l}2.3 \\
3.6\end{array}$ \\
\hline \multicolumn{6}{|l|}{ Age (years) } \\
\hline $\begin{array}{l}<25 \\
25-29 \\
\geq 30\end{array}$ & $\begin{array}{r}810 \\
1283 \\
1228\end{array}$ & $\begin{array}{l}6.1 \\
5.5 \\
5.0\end{array}$ & $\begin{array}{r}9.1 \\
9.5 \\
10.2\end{array}$ & $\begin{array}{l}44.9 \\
38.7 \\
33.1^{1++}\end{array}$ & $\begin{array}{l}3.7 \\
3.0 \\
3.3\end{array}$ \\
\hline \multicolumn{6}{|l|}{ Parity } \\
\hline $\begin{array}{l}0 \\
\geq 1\end{array}$ & $\begin{array}{l}1615 \\
1706\end{array}$ & $\begin{array}{l}6.8 \\
4.1^{* *}\end{array}$ & $\begin{array}{l}5.7 \\
* \\
* 13.5^{* * *}\end{array}$ & $\begin{array}{l}32.5 \\
* 43.8^{* * *}\end{array}$ & $\begin{array}{l}4.3 \\
2.4^{* *}\end{array}$ \\
\hline \multicolumn{6}{|l|}{ Education } \\
\hline $\begin{array}{l}\text { Primary or secondary I } \\
\text { Secondary } \| \\
\text { College/ } \\
\text { university }\end{array}$ & $\begin{array}{r}861 \\
1334\end{array}$ & $\begin{array}{l}4.8 \\
5.9\end{array}$ & $\begin{array}{l}10.0 \\
10.8\end{array}$ & $\begin{array}{l}45.8 \\
40.3\end{array}$ & $\begin{array}{l}4.2 \\
3.5\end{array}$ \\
\hline \multicolumn{6}{|l|}{ Partner's education } \\
\hline $\begin{array}{l}\text { Primary or secondary I } \\
\text { Secondary II } \\
\text { College/ } \\
\text { University }\end{array}$ & $\begin{array}{r}800 \\
1253\end{array}$ & $\begin{array}{l}6.3 \\
4.9\end{array}$ & $\begin{array}{r}11.7 \\
9.6\end{array}$ & $\begin{array}{l}43.9 \\
39.0 \\
31.0^{+++}\end{array}$ & $\begin{array}{l}3.9 \\
3.2 \\
2.1^{+}\end{array}$ \\
\hline \multicolumn{6}{|l|}{ Daily smoking } \\
\hline $\begin{array}{c}\text { No } \\
\text { Yes } \\
\text { Coffee }\end{array}$ & $\begin{array}{r}2430 \\
881\end{array}$ & $\begin{array}{l}6.2 \\
3.3^{* *}\end{array}$ & $\begin{array}{l}8.4 \\
13.3^{* * *}\end{array}$ & ${ }^{35.7} 45.1^{* * *}$ & $\begin{array}{l}2.6 \\
5.5^{\star \star \star *}\end{array}$ \\
\hline $\begin{array}{l}\leq 4 \text { cups } \\
\geq 4 \text { cups }\end{array}$ & $\begin{array}{r}2803 \\
465\end{array}$ & $\begin{array}{l}5.3 \\
6.2\end{array}$ & $\begin{array}{c}8.8 \\
14.6^{* * *}\end{array}$ & $\begin{array}{l}37.1 \\
44.7^{* * *}\end{array}$ & $\begin{array}{l}3.1 \\
4.8\end{array}$ \\
\hline Total & 3321 & 5.4 & 9.8 & 37.4 & 3.3 \\
\hline
\end{tabular}

3 Percentages are based on respondents with complete information.

${ }^{*} P<0.05,{ }^{* \star} P<0.01,{ }^{* \star *} P<0.001$ (Pearson chi-square).

$+P<0.05,{ }^{++} P<0.01,{ }^{+++} P<0.001$ (Mantel-Haenszel's trend test).
Education (maternal and paternal) was registered as the highest completed level of education (primary or secondary 9-10 years; secondary $11-12$ years; college or university). Smoking during pregnancy was recorded as the number of cigarettes daily, and coffee consumption was registered as the number of cups daily.

Questionnaire data on age (completed years at the end of 1989), parity, and maternal education agreed well with information about the same population from the Medical Birth Registry of Norway and Statistics Norway.

Questions on smoking and work conditions were tested for reliability by asking a group of 60 women (45 in paid work) the same questions at an interval of $6-10$ weeks (before and after delivery). The kappa coefficients (א) (24) for data on smoking were 0.9 for retest and 0.8 when compared with data on medical records. Agreement was fair $(\kappa=0.5-0.9)$ for all the work condition variables, but the question on job content was not pretested.

The study protocol was approved by the regional ethics committee (health region II in Norway, covering Oslo).

In the data analysis, bivariate associations with preeclampsia, pelvic pain, low-back pain, and low birthweight as dependent variables were tested for statistical significance with the Pearson chi-square test and Mantel-Haenszel's test for trend. The independent variables examined were the 3 describing different types of control over work pace (influence on breaks, influence on work pace, and absence of external pacing), 6 additional work condition variables (manual work, heavy lifting, work with video display terminals, influence on job content, weekly hours of housework, weekly hours of paid work), 5 maternal characteristics (age, parity, education, smoking, coffee consumption), and partner's education. Low-back pain was also examined as an independent variable for association with pelvic pain.

Crude and adjusted odds ratios at each score level were estimated by logistic regression. Age, parity, maternal education, and smoking were entered in the final multivariate model, as variables of interest. The other independent variables listed in table 1 , and not included in the score, were examined as potential confounders and included in the final model if they led to a biologically important change in the estimated coefficients for score levels (25), operationally defined as around $20 \%$. Smoking, parity, manual work, and heavy lifting were examined for interaction with the score.

Odds ratios give poor estimates of effect in studies of common conditions like low-back pain and cannot be interpreted as approximations of relative risk (26). Relative risk (RR) can be expressed by the odds ratio (OR) and the prevalence $(\mathrm{P})$ of disease in the reference category, as $\mathrm{OR} /[(1 \mathrm{P})+\mathrm{OR} \cdot \mathrm{P}]$. An approximate relative risk was calculated for low-back pain by the same formula, with the adjusted odds ratio entered for the odds ratio. 
A test for trend was obtained by treating the score as interval-scaled in the multivariate analysis.

To examine the effects of eventual overreporting of manual work and heavy lifting by cases of low-back pain and disabling pelvic pain, the multivariate analyses were repeated after every second of the cases that reported heavy lifting or manual work was recoded to unexposed.

In the assessment of the magnitude of eventual information bias, 16 main female occupational groups (27) were classified according to control over work pace as perceived by noncases (ie, women without any of the outcomes studied) (28). The occupational groups were classified as "high control" if the fraction of noncases reporting high control (score value 3 ) was above average; otherwise it was recorded as "low control". For each of the 4 outcomes, the fraction of all cases with self-reported high control (score 3 ) found in "high control" occupations was then divided by the fraction of all noncases with a score of 3 in "high control" occupations (29). In the same way, the fraction of all cases with self-reported medium, low, or no control (score $<3$ ) found in "low control" occupations was divided by the fraction of all noncases with a score of $<3$ in "low control" occupations.

Spearman's correlation coefficient (22) did not exceed 0.7 for any pair of variables included in the multivariate analyses. The significance level was defined as alpha $=0.05$ (2-tailed test). The analyses were carried out with SPSS (30).

\section{Results}

In the study population of 3321 women, there were 180 $(5.4 \%)$ cases of preeclampsia and $110(3.3 \%)$ cases of low birthweight. Of the 3074 women with complete information on back pain, pelvic pain, and disability, 302 (9.8\%) met the case definition for disabling pelvic pain. The total number with low-back pain (with or without pelvic pain) was $1150(37.4 \%)$. Disabling pelvic pain was more prevalent among the women with low-back pain (19.2\% versus $4.2 \%, \mathrm{P}<0.001)$.

Altogether 1285 women (41.8\%) reported "pelvic girdle loosening", of whom 739 (24\%) simultaneously reported low-back pain. The total number with back pain (low-back pain or pelvic girdle loosening or both) was $1696(55.1 \%)$.

Table 1 presents the bivariate associations between independent variables and the 4 outcomes. Weekly hours of housework was not associated with any of the outcomes.

The prevalences of all outcomes decreased with increasing score values (table 2). For low-back pain the association was restricted to nullipara. The crude odds ratios (OR) with their $95 \%$ confidence intervals (95\% CI) for no control (score 0 ) versus high control (score 3 ) were $1.6(95 \%$ CI $0.9,2.8)$ for preeclampsia, $1.9(95 \% \mathrm{CI}$ $1.2,2.8)$ for disabling pelvic pain, 2.0 (95\% CI 1.5,2.6) for low-back pain (equivalent to a crude relative risk of 1.5), and 2.7 (95\% CI 1.1,6.9) for low birthweight in nullipara.

Including age, parity, smoking, and maternal education in the model had little effect on the associations with the work pace score, while the inclusion of manual work reduced the risks of disabling pelvic pain and low-back pain. None of the other variables examined, like paternal education, heavy lifting or weekly hours in paid work, had a confounding effect, except that low-back pain was a confounder of the association with disabling pelvic pain. Neither manual work nor heavy lifting was an effect modifier.

Table 2. Prevalence ${ }^{a}$ of preeclampsia (PE), disabling posterior pelvic pain (DPP), low-back pain (LBP), and low birthweight (LBW) according to the score for work pace control among women in paid work beyond the 3rd month of pregnancy, with single births. The odds ratios $(\mathrm{OR})$ were adjusted for age, parity, education, smoking, and manual work (disabling posterior pelvis pain also adjusted for low-back pain).

\begin{tabular}{|c|c|c|c|c|c|c|c|c|c|c|c|c|c|c|}
\hline \multirow[t]{2}{*}{ Category } & \multirow{2}{*}{$\begin{array}{l}\text { Number of } \\
\text { respondents }\end{array}$} & \multicolumn{3}{|c|}{$P E$} & \multicolumn{3}{|c|}{$\mathrm{DPP}$} & \multicolumn{3}{|c|}{ LBP } & \multicolumn{4}{|c|}{ Nullipara LBW } \\
\hline & & $\%$ & $\begin{array}{c}\text { Adjusted } \\
\mathrm{OR}^{\mathrm{b}}\end{array}$ & $95 \% \mathrm{Cl}$ & $\%$ & $\begin{array}{c}\text { Adjusted } \\
\mathrm{OR}^{\mathrm{c}}\end{array}$ & $95 \% \mathrm{Cl}$ & $\%$ & $\begin{array}{c}\text { Adjusted } \\
\text { ORd }^{d}\end{array}$ & d $95 \% \mathrm{Cl}$ & N & $\%$ & $\begin{array}{c}\text { Adjusted } \\
\mathrm{OR}^{\mathrm{a}}\end{array}$ & $95 \% \mathrm{Cl}$ \\
\hline $\begin{array}{l}0 \text { no control } \\
1 \text { low } \\
2 \text { medium } \\
3 \text { high control } \\
\text { Missing }\end{array}$ & $\begin{array}{r}327 \\
985 \\
1108 \\
826 \\
75\end{array}$ & $\begin{array}{l}5.8 \\
6.2 \\
5.8 \\
3.8\end{array}$ & $\begin{array}{l}1.6 \\
1.8 \\
1.7 \\
1.0\end{array}$ & $\begin{array}{l}0.9-3.1 \\
1.1-2.9 \\
1.1-2.7\end{array}$ & $\begin{array}{r}14.6 \\
8.9 \\
9.7 \\
8.4\end{array}$ & $\begin{array}{l}1.6 \\
1.0 \\
1.1 \\
1.0\end{array}$ & $\begin{array}{l}1.0-2.4 \\
0.7-1.4 \\
0.8-1.5\end{array}$ & $\begin{array}{l}49.7 \\
39.3 \\
36.8 \\
33.5\end{array}$ & $\begin{array}{l}1.3 \\
1.1 \\
1.0 \\
1.0\end{array}$ & $\begin{array}{l}1.0-1.8 \\
0.9-1.3 \\
0.8-1.2\end{array}$ & $\begin{array}{r}160 \\
474 \\
532 \\
417 \\
32\end{array}$ & $\begin{array}{l}5.7 \\
5.7 \\
4.1 \\
2.2\end{array}$ & $\begin{array}{l}2.5 \\
2.6 \\
2.0 \\
1.0\end{array}$ & $\begin{array}{l}0.9-6.8 \\
1.1-6.0 \\
0.9-4.5\end{array}$ \\
\hline Total & 3321 & 5.4 & & & 9.7 & & & 38.0 & & & 1615 & 4.3 & & \\
\hline P-value (trend test') & & $<0.05$ & $<0.05$ & & $<0.05$ & 0.2 & & $<0.001$ & 0.08 & & & $<0.01$ & $<0.05$ & \\
\hline
\end{tabular}

a Percentages are based on respondents with complete information. ${ }^{b}$ Complete data set for $3179 .{ }^{\circ}$ Complete data set for 2964 . ${ }^{d}$ Complete data set for 3029. e Complete data set for 1556. 'Mantel-Haenszel's test for trend in the bivariate analyses. P-value of the score coefficient with the score as the interval-scaled variable in the multivariate analysis. 
The adjusted odds ratio for no control versus high control was 1.6 (95\% CI 0.9-3.1) for preeclampsia, 1.6 (95\% CI $1.0-2.4)$ for disabling pelvic pain, $1.3(95 \% \mathrm{CI}$ $1.0-1.8$ ) for low-back pain (approximate RR 1.2), and 2.5 (95\% CI 0.9-6.8) for low birthweight in nullipara.

Correcting for eventual bias from the overreporting of heavy lifting and manual work by cases of disabling pelvic pain and low-back pain only affected the odds ratios for low-back pain. The adjusted odds ratio for no control versus high control increased from 1.3 to 2.0 , and the decreasing trend in the odds ratios with increasing control became statistically significant $(\mathrm{P}<0.001)$.

The ratios calculated to assess the magnitude of information bias were close to unity and therefore did not indicate notable bias. The ratio of the fraction of cases to the fraction of noncases with self-reported high control in high control occupations was 0.87 for preeclampsia, 1.15 for disabling pelvic pain, 0.89 for low-back pain, and 1.07 for low birthweight. The corresponding ratios for the cases and noncases with self-reported medium, low, or no control in low control occupations were 0.93 , $0.94,0.97$, and 1.02 , respectively. The differences between the comparable fractions of cases and noncases were not significant.

The prevalence of women with high control (score 3) was above average for administrative and executive work, accounting, bookkeeping, secretarial work and stenography, clerical work, cleaning, and social work. The prevalence of women with no control (score 0 ) was above average for staff nurses and practical nurses, nursery school teachers, shop and restaurant cashiers, industrial workers, kitchen assistants, and waitresses.

\section{Discussion}

Women in paid work with the power to control their own work pace had better pregnancy health than women without such power when pregnancy health was defined by the prevalences of preeclampsia, posterior pelvic pain, low-back pain, and low birthweight. The effect was observed in both nonmanual and manual work.

Adjustment for age, maternal education, smoking, and parity had little effect, while adjustment for manual work slightly reduced the risk of posterior pelvic pain and low-back pain in association with lack of control.

The cross-sectional design with a collection of information after birth was chosen to obtain an unselected, national sample of parturients. Deliveries in Norway are centralized, with more than $99 \%$ occurring in maternity institutions in 1989, while prenatal care is decentralized.

The design entailed the possibility of information bias. The questionnaire did not focus on lack of control as a risk factor, but there still might have been relative underreporting of adverse conditions by noncases in comparison with cases.

For an assessment of exposure information bias, exposure to video display terminals was included as a "fake risk factor" (31). When the study was conducted, there was widespread public concern regarding work with such terminals as a risk factor in pregnancy. Influence on work content was examined as an independent variable on the assumption that biased recall would be similar across different types of job control. The fact that, with 1 exception, no positive association was found with these variables speaks against considerable information bias for cases versus noncases of conditions perceived as adverse. Moreover, only low-back pain was associated with all 3 work-pace control variables, a pattern to be expected for all outcomes if there had been extensive differential misreporting of exposure.

Musculoskeletal pain may bias the self-assessment of lifting or strenuous postures $(32,33)$, and the associations observed between heavy lifting or manual work and low-back pain may therefore have partly been due to relative overreporting by cases. Calculations showed that the consequence of such bias in the present study would apparently have been an underestimation of the association between lack of control and the risk of low-back pain.

A comparison of fractions of cases and noncases within occupations classified according to the level of control, as reported by noncases, did not indicate notable exposure information bias.

Occupational groups and the average level of exposure within each group, reported by noncases, can sometimes serve as unbiased, proxy measures of exposure (27). In the present study, this method was not suitable due to the great variation in the individual perception of control within each occupational group.

Misreporting could have affected the outcome variables. The validity of the data on birthweight and preeclampsia has been discussed elsewhere and compared with that of data recorded by the Medical Birth Registry (21, 27). The prevalence of self-reported "pelvic girdle loosening" and low-back pain was somewhat higher than previously reported for clinically ascertained cases. Östgaard et al (34) found that the proportion with pelvic pain increased during early pregnancy to become stable, around $35 \%$, from the 22 nd to the 24 th week. The proportion with "pelvic girdle loosening" in the present study had only reached $25 \%$ at the early stage, but it continued to increase throughout pregnancy to reach $42 \%$. A somewhat larger proportion of women with self-reported "pelvic girdle loosening" versus clinically ascertained posterior pelvic pain was to be expected, but the difference in late pregnancy incidence remains unexplained. Pain drawings may facilitate the differentiation between types of back pain in future questionnaire-based studies (34). 
The case definition of disabling pelvic pain favored cases with onset in early pregnancy and cases among parous women with a larger domestic work load. The association with work pace control was, however, independent of parity.

Rapid work pace has been identified as a risk factor for term low birthweight (35) and hypertensive disorders in pregnancy $(14,36)$. The results of the present study are in accordance with these findings, on the assumption that women who control their work pace can avoid excessive demands for speed. The results also support the identification of an inability to take rest breaks as a risk factor for back pain (19).

Other studies have found that the duration of work may be important for the effect of physically demanding work on fetal growth (37) and gestational age (38). Weekly workhours was not a confounder of the association between pregnancy health and control over work pace. One reason may be that part-time work was strongly associated with parity in the study population (ie, with greater domestic, usually physically demanding, work load).

The restriction of effects on low birthweight to nullipara may have been due to a higher prevalence of conditions with potentially greater susceptibility, like intrauterine growth retardation and hypertension in pregnancy. Moreover, a greater domestic work load may reduce the relative importance of conditions in paid work for parous women.

Henriksen et al (39) found increased risk for preterm delivery and small-for-gestational age deliveries among women with low-control jobs, but none of the findings were statistically significant. Control over work pace may be a better determinant of pregnancy health than the wider concept of job control used by Henriksen et al (39). Research has linked various constraints on individual control over work pace to musculoskeletal and cardiovascular disorders in nonpregnant populations $(1,3,7$, $8)$. The score items employed to define control over work pace in this study deal with individual freedom to decide about work pace. Such control can be regarded as one particular aspect of decision authority as the concept is employed by Karasek et al (40). The low intercorrelation between the 3 items as measured by Cronbach's alpha may reflect an inequality between the measures for some occupations.

The concept of control was operationally defined as perceived, self-reported control. This definition corresponds to the type of information available in the prenatal clinic, namely, information about perceived, rather than externally ascertained work conditions.

The study design does not permit conclusions about causality. Nevertheless, the biological plausibility of the results and the potentially broad preventive effects makes increased power to control one's own work pace a prime target for job adjustment in pregnancy and an important topic for intervention studies.

\section{Acknowledgments}

The authors greatly appreciate the advice given by $\mathrm{Dr}$ Tor Bjerkedal and Dr Odd Aalen of the University of Oslo, and by Dr Per E. Børdahl of the National Hospital. We also wish to thank the maternity wards all over Norway, which assumed the responsibility of distributing and collecting the questionnaires, and, not the least, the women who completed them. Eli Heiberg was a co-worker in the questionnaire study. The Medical Birth Registry of Norway and Statistics Norway provided information on the study population.

The study was supported by research grants from the Norwegian Research Council, the Work Environment Fund of the Confederation of Norwegian Business and Industry, and the Borregaard a/s Research Fund.

\section{References}

1. Kilbom $\AA$. Belastningsskador och arbetsorganisation [Strain injuries and work organization]. In: Winkel J, Kilbom $\AA$, editors. Fysisk belastning och tidsaspekter på arbetsorganisation vid repetitivt och monotont arbete [Physical load and time aspects of work organisation by repetitive and monotonous work]. Stockholm: Arbetsmiljöinstitutet, 1989;21:617. Undersökningsrapport.

2. Statistics Norway. Working environment 1993. Oslo: Statistics Norway, 1995;29.

3. Åstrand I. Physical demands in worklife. Scand J Work Environ Health 1988;14 suppl 1:10-3. 3 .

4. Åstrand I, Åstrand PO, Christensen EH, Hedman R. Intermittent muscular work. Acta Physiol Scand 1960;48:448 - 53.

5. Grandjean E. Fitting the task to the man: an ergonomic approach. London: Taylor \& Francis Ltd, 1980:229-35.

6. Lehmann G. Praktische Arbeitsphysiologie. Stuttgart: Georg Thieme Verlag, 1962:51-72.

7. Steptoe A, Fieldman G, Evans O. An experimental study of the effects of control over work pace on cardiovascular responsivity. J Psychophysiol 1993;7:290-300.

8. Bohlin G, Eliasson K, Hjemdahl P, Klein K, Frankenhaeuser M. Pace variation and control over work pace as related to cardiovascular, neuroendocrine and subjective responses. Biol Psychol 1986;23:247-63.

9. Wallace JP, Wiswell RA. Maternal cardiovascular response to exercise during pregnancy. In: Mittelmark RA, Wiswell RA, Drinkwater BL, editors. Exercise in pregnancy. 2nd ed. Baltimore (MD): Williams and Wilkins, 1991:195-205.

10. Karzel RP, Friedman MJ. Orthopedic injuries in pregnancy. In: Mittelmark RA, Wiswell RA, Drinkwater BL, editors. Exercise in pregnancy. 2nd ed. Baltimore (MD): Williams and Wilkins, 1991:123-32.

11. Chamberlain GV. Work in pregnancy. Am J Ind Med 
1993;23:559--75.

12. Roberts JM, Redman CWG. Pre-eclampsia: more than pregnancy-induced hypertension. Lancet 1993;341:1447-51.

13. Saurel-Cubizolles MJ, Kaminski M, du Mazaubrun C, Llado J, Estryn-Behar M. High blood pressure during pregnancy and working conditions among hospital personnel. Eur $\mathrm{J} \mathrm{Ob}-$ stet Gynecol Reprod Biol 1991;40,29-34.

14. Saurel-Cubizolles MJ, Kaminski M, du Mazaubrun C, Breart G. Les conditions de travail professionel des femmes et l'hypertension arterielle en cours de grossesse. Rev Epidemiol Santé Publ 1991;39:37-43.

15. Nurminen T, Lusa S, Ilmarinen J, Kurppa K. Physical work load, fetal development and course of pregnancy. Scand $\mathrm{J}$ Work Environ Health 1989;15:404-14.

16. Kristiansson P, Svardsudd K, von Schoultz B. Serum relaxin, symphyseal pain and back pain during pregnancy. Am J Obstet Gynecol 1996;175:1342-7.

17. Paul JA, van Dijk FJH, Frings-Dresen MHW. Work load and musculoskeletal complaints during pregnancy [review]. Scand J Work Environ Health 1994;20:153-9.

18. Cherry N. Physical demands of work and health complaints among women working late in pregnancy. Ergonomics 1987;40:689-701.

19. Östgaard HC, Andersson GBJ, Karlsson K. Prevalence of back pain in pregnancy. Spine 1991;5:549-52.

20. Östgaard HC, Zetherström G, Roos-Hansson E, Svanberg B. Reduction of back and posterior pelvic pain in pregnancy. Spine 1994;19:894-900.

21. Wergeland E, Strand K. Working conditions and prevalence of pre-eclampsia, Norway 1989. Int J Gyn Obst 1997;58:189-96.

22. Colton T. Statistics in medicine. Boston (MA): Little, Brown and Company, 1974:223-4.

23. Zeller RA, Carmines EG. Measurement in the social sciences. London: Cambridge University Press, 1980:56-8.

24. Fleiss JL. Statistical methods for rates and proportions. 2nd ed. New York (NY): John Wiley and Sons, 1981:217.

25. Hosmer DW, Lemeshow S. Applied logistic regression. New York (NY): John Wiley \& Sons, 1989:67.

26. Axelsson O. Some recent developments in occupational epidemiology. Scand J Work Environ health 1994;20 special issue:9-18.
27. Wergeland E, Strand K, Børdahl PE. Strenuous working conditions and birthweight, Norway 1989. Acta Obst Gynecol Scand. In press.

28. Axelson O. A note on observational bias in case-referent studies in occupational health epidemiology [letter to the editor]. Scand J Work Environ Health 1980;6:80 -2.

29. Basso O, Olsen J, Bisanti L, Karmaus W. The performance of several indicators in detecting recall bias. Epidemiology 1997;8:269-74.

30. SPSS Inc. SPSS/PC+ 4.0. The statistical package for IBM PC. Chicago (IL): SPSS Inc, 1990.

31. Raphael K. Recall Bias: a proposal for assessment and control. Int J Epidemiol 1987:16:167 - 70 .

32. Viikari-Juntura E, Rauas S, Martikainen R, Kuosma E, Riihimäki H, Takala E-P, et al. Validity of self-reported physical work load in epidemiologic studies on musculoskeletal disorders. Scand J Work Environ Health 1996;22:251-9.

33. Wiktorin C, Karlqvist L, Winkel J, Stockholm MUSIC I study group. Validity of self-reported exposures to work postures and manual materials handling. Scand J Work Environ Health 1993;19:208-14.

34. Östgaard HC. Assessment and treatment of low back pain in working pregnant women. Semin Perinatol 1996;1:61—9.

35. Brandt LPA, Nielsen CV. Job stress and adverse outcome of pregnancy: a causal link or recall bias? Am J Epidemiol 1992;135:302-11.

36. Klonoff-Cohen HS, Cross JL, Pieper CF. Job stress and preeclampsia. Epidemiology 1996;7:245 —9.

37. Hatch M, Bu-Tian J, Shu XO, Susser M. Do standing, lifting, climbing, or long hours of work during pregnancy have an effect on fetal growth? Epidemiology 1997;8:530-6.

38. Koemeester AP, Broersen JP, Treffers PE. Physical work load and gestational age at delivery. Occup Environ Med 1995;52:313-5.

39. Henriksen TB, Hedegaard M, Secher NJ. The relation between psychosocial job strain and preterm delivery and low birthweight for gestational age. Int $\mathrm{J}$ Epidemiol 1994;23:764-74.

40. Karasek R, Theorell T. Healthy work. New York (NY): Basic Books Inc Publishers, 1990:58—61.

Received for publication: 12 August 1997 